\title{
LABOR RELATIONS, UNIONS AND COLLECTIVE BARGAINING: A POLITICAL ECONOMIC ANALYSIS
}

\author{
Walter Block \\ College of the Holy Cross, Aminerst
}

It is not difficult to document the fact that many segments of our society extol the virtues of unionism, as commonly practiced. Some people defend unions as a means of promoting employment. Others feel that "social justice" is a sufficient warrant for this curious institution. So deeply embedded in our folkways is the concept that unions are legitimate institutions that many mainline religious organizations have even gone so far as to invite them to organize their own Church employees - on what they see as moral grounds.

The simple fact is thar: in the minds of most pundits, unions have a legitimate role to play in our society. How else can we account for the fact that gangs of organized laborers who have engaged in violent strikes not only still remain at large, but are widely applauded for their courage and convictions? Were any other group of people to have interfered with the lives and property of others in a similar manner, they would have been summarily clapped into jail, and been considered proper objects of fear, loathing, ridicule and pity, the reaction elicited in most people by activities criminal.

\section{Complexity}

Contrary to the popular notion, however, unionism is a complex phenomenon, which admits of a voluntary and a coercive aspect. The philosophy of free enterprise is fully consistent with voluntary unionism, but is diametrically opposed to coercive unionism. What do all varieties of unionism, both coercive and voluntary, have in common? Unions are associations of employees, organized with the purpose of bargaining with their employer in order to increase their wages.'

'Since money wages are funds which the employees take home, and working 
What, then, is the distinction between invasive and noninvasive unions? The latter obey the libertarian axiom of nonaggression against non-aggressors; the former do not. Legitimate unions, in other words, limit themselves to means of raising wages which do not violate the rights of others; illegitimate unions do not so inhibit themselves.

Some pundits have declared their "full support for the principle of free and voluntary association in labor unions." If this constitutes moral approval of voluntary unions, and condemnation of the coercive type, well and good. But if it is intended to apply to extant labor organizations, this statement is disingenuous. It is not even a rough approximation of how organized labor has operated - and still continues to operate in the modern world.

\section{Coercion}

Let us be absolutely clear on this distinction, for it is at the root of any accurate assessment of unionism. There are those labor organizations which do all they can to raise their members' wages and working conditions - except violate the (negative) rights of other people by initiating violence against them. These can be properly called "voluntary unions". But then there are those which do all they can to promote their members' welfare both by legitimate non-rights-violative behavior as well as by the use of physical brutality aimed at non-aggressing individuals.

With regard to the activity of "coercive unions" defined in this manner, Ludwig von Mises has stated:

conditions embody funds which are spent, at least in part, in behalf of the employees while on the job, there are really two desiderata here. One, the total of money wages and working conditions, and two, the allocation between them. On the free market, the employer has a great incentive to allocate these two sorts of wage expenditures in accordance with the desires of his employees. If, for example, the workers in his plant prefer most of their wages in the form of take-home-pay, and very little in the form of expenditure for amenities on the job site, the employer who ignores this desire (or, equivalently, fails to ferret out this information) will suffer higher quit rates - or else he will have to increase his total wage package, in order to compele with other employers who are better able to discern employee lastes in this matter.
... labor unions have actually acquired the privilege of violent action. The governments have abandoned in their favor the essential attribute of government, the exclusive power and right to resort to violent coercion and compulsion. Of course, the laws which make it a criminal offense for any citizen to resort - except in case of self-defense - to violent action have not been formally repealed or amended. However, actual labor union violence is tolerated within broad limits. The labor unions are practically free to prevent by force anybody from defying their orders concerning wage rates and other labor conditions. They are free to inflict with impunity bodily evils upon strikebreakers and upon entrepreneurs who employ strikebreakers. They are free to destroy property of such employers and even to injure customers patronizing their shops. The authoricies, with the approval of public opinion, condone such acts ... In excessive cases, if the deeds of violence go too far, some lame and timid attempts at repression and prevention are ventured. But as a rule they fail ... What is euphemistically called collective bargaining by union leaders and 'pro-labor' legislation is of a quite different character. It is bargaining at the point of a gun. It is bargaining between an armed party, ready to use its weapons, and an unarmed party under duress. It is not a market transaction. It is a dictate forced lipon the employer ... It produces institutional unemployment.

The treatment of the problems involved by public opinion and the vast number of pseudo-economic writings is utterly misleading. The issue is not the right to form associations. It is whether or not any association of private citizens should be granted the privilege of resorting with impunity to violent action.

Neither is it correct to look upon the matter from the point of view of a 'right to strike.' The problem is not the right to strike, but the right - by-intimidation or violence to force other people to strike, and the further right to prevent anybody from working in a shop in which a union has called a strike. (Ludwig von Mises, 1966, pp. 777-79). 


\section{And in the view of Friedrich Hayek:}

It cannot be stressed enough that the coercion which unions have been permitted to exercise contrary to all principles of freedom under the law is primarily the coercion of fellow workers. Whatever true coercive power unions may be able to wield over employers is a consequence of this primary power of coercing other workers; the coercion of employers would lose most of its objectionable character if unions were deprived of this power to exact unwilling support. Neither the right of voluntary agreement between workers nor even their right to withhold their services in concert is in question. (F.A. von Hayek, 1960, p. 269.) ${ }^{2}$

Given that there are legitimate and illegitimate forms of labor organization, it follows that sound public policy consists of defending the former and eliminating the latter. In legai terminology, this reduces to a call for the repeal of legislation that promotes invasive action, and for an expansion of the legal protections for non-invasive ones. In the just society, a union may do anything that individual citizens have a right to do, and must refrain from all activities prohibited to other citizens. The labor code, in other words, ought be nothing more than the ordinary rule of law (Hayek, 1973; Leoni, 1961, pp. 59-76), applied to management-labor relations.

This leads us to the $\$ 64,000$ question. Which arrows in the quiver of organized labor are invasive, and which are not? Let us start off by mentioning several legitimate techniques utilized by organized labor, and then look at the panoply of illegitimate actions engaged in by unions.

\section{Legitimate Unionism}

\section{Mass Walkout}

First is the mass walkout: threatening, or organizing, a mass

$\therefore$ Savs Morgan O. Revuolds 1984. p. 50: "Hittir:g a person o:cr the head with a baseball bat is much less likety to be treated as criminal if the person wielding the bat is an organized (i.e. unionized) worker in a labor dispute." See also Hutt. 1999. walk out, unless wage demands are met. $^{3}$. This is not an infringement of anyone's rights, since the employer, in the absence of a contract, cannot compel people to work for him at wages they deem too low. Nor is it any valid objection to this procedure that the workers are acting in concert, or in unison, or in collusion, or in "conspiracy." Of course they are. But if it is proper for one worker to quit his job, then all workers, together, have every right to do so, en masse. ${ }^{3}$ All conspiracy laws ought to be repealed, provided only that the agreement is to do something that would be legal when undertaken by a single individual.

There are numerous conservatives, as opposed to libertarians, who take the view that anti-trust and anti-combines law ought to be applied to unions. ${ }^{6}$ Thus, even what we have been describing as voluntary unions would be for them illegitimate, because they claim that "collusive actions" on the part of unions "exploit' the community as a whole," in their violation of consumers' sovereignty. ${ }^{3}$ But this only shows that there is all the world of difference between economists who support the system of laissez-faire capitalism, on the one hand, and those who favor a system of national or state capitalism on the other.

'This is on the assumption that there is no vaid employment contract in effect at this time which prohibits such an act.

'This follows directly from a defense of voluntary socialism, vis a vis coercive Voluntary unionism is merely one facet of the former. For an elaboration of this point, see Waiter Block, 1990.

This is not a violation of the law of composition, or an instance of this fallacy. The only serious challenge to the textual statement is the case where harms can be additive. For example, the scenario where if one person touches another, slightly, it is not a rights violation, because no harm is done, whereas if a million persons do so, the victim can indeed be harmed, and thus there is a rights violation. The difficulty with this line of armument, though, is that even the first slight touching, done by only one person, is an illicit act, even though the harm is slight, or even non existent, provided only that the vicuims person has been incerfered with. See (to be supplied).

${ }^{6}$ In contrast. libertarians take the view that anti-trust and anti-combines legisiation ought not be applied to anvone, neither unions nor business firms. See Armentano 1972. 1982:.

(II. II. It1t: (1973. p.3. 1989); Schmide (1973); Simons (1948). In sharp distinction. for a liberta rian analysis which defends the right of organized labor to threates or to quit in unison. see Petro (1957); Reynolds (1984).

'For a critique of Hutt, see Murray N. Rothbard (1970. pp. 561-566). 


\section{Back to Work Legislation}

Again, libertarians would disagree with many "right-wing" conservatives on the question as to whether it is improper for governments to enact legislation forcing unions back to work where a union strike threatens to disrupt broad segments of the economy and to harm innocent parties not involved in the dispute. The libertarian viewpoint holds that the government does not have such a right, and that this follows from the basic libertarian premise of self-ownership. In the words of Murray Rothbard (1978, pp. 83, 84):

On October 4, 1971, President Nixon invoked the TaftHartley Act to obtain a court injunction forcing the suspension of a dock strike for eighty days; ... It is no doubt convenient for a long suffering public to be spared the disruptions of a strike. Yet the 'solution' imposed was forced labor, pure and simple; the workers were coerced, against their will, into going back to work. There is no moral excuse, in a society claiming to be opposed to slavery and in a country which has outlawed involuntary servitude, for any legal or judicial action prohibiting strikes - or jailing union leaders who fail to comply.

Conventional conservatives tend to place the national good above the good of individuals, so there is a basic disagreement between right-wing conservatives and libertarians on this issue.

\section{Boycott}

Another activity held to be legitimate by libertarians is the boycott, whether primary or secondary. A boycott is simply the refusal of one person to deal with another. ${ }^{9}$ All interaction in

Thus, all anti-discriminatory laws are incompatible with the libertarian legal code. For an analysis which shows that such legisiation is itself a rights violation, and that the free marketplace is the best protector of liberties, see friedman (1985), Sowell (1983) Williams (1982).

It is logically inconsistent to maintain that people do not have the right to discriminate against one another, and that they do have the right to boycott, since the boycott is merely an orchestrated discriminacion against certain individuais or groups a free society must be on a mutual basis, but there is no presumption that any particular interaction must take place. It is part and parcel of the law of free association that any one person may refuse to associate with another for any reason that seems sufficient to him. Since a boycott is merely an organized refusal to deal with another, and each person has a right to so act, then people may act in this way in concert. A "hot edict," whereby a union declares the handling of certain products to be prohibited by organized labor, is a special case of the boycott. Provided that there is no contract in force which is incompatible with such a declaration, it, too, is an entirely legitimate activity. Says Rothbard (1983, p.131) in this regard:

A boycott is an attempt to persuade other people to have nothing to do with some particular person or firm - either socially or in agreeing not to purchase the firm's product. Morally, a boycott may be used for absurd, reprehensible, laudatory or neutral goals. It may be used, for example, to attempt to persuade people not to buy non-union grapes or not to buy union grapes. From our point of view, the important thing about the boycott is that it is purely voluntary, an act of attempted persuasion, and therefore that it is a perfectly legal and licit instrument of action ... a boycott may well diminish a firm's customers and therefore cut into its property values; but such an act is still a perfectly legitimate exercise of free speech and property rights. Whether we wish any particular boycott well or ill depends on our moral values and on our attitudes toward the concrete goal or activity. But a boycott is legitimate per se. If we feel a given boycott to be morally reprehensible, then it is within the rights of those who feel this way to organize a counter boycott to persuade the consumers otherwise, or to boycott the boycotters. All this is part of the process of dissemination of information and opinion within the framework of the rights of private property.

of people. 
Furthermore, 'secondary' boycotts are also legitimate, despite their outlawry under our current labor laws. In a secondary boycott, labor unions try to persuade consumers not to buy from firms who deal with non-union (primary boycotted) firms. Again, in a free society, it should be their right to try such persuasion, just as it is the right of their opponents to counter with an opposing boycott.

\section{Sorenson}

An illustracion of this principle took place in Canada. Alderman Bill Sorenson of North Vancouver City had voted to contract out the municipal garbage collection services to private enterprise. And, to add insult to injury - at least in the eyes of Local 389 of the Canadian Union of Public Employees (CUPE) - he also voted for a wage freeze covering all city employees.

The union didn't take long to strike back.

As it happens, Sorenson was the operations manager for the North Shore Community Credit Union, a local banking facility. As it also happens, Local 389 of CUPE holds deposits with this credit union. In response to Alderman Sorenson's votes on city council, the Union withdrew $\$ 25,000$ of its funds from the bank which employed Sorenson.

Now this decision to withdraw funds was no mere coincidence. It was motivated by spite - an attempt to get back at a part-time politician by attacking him in his capacity as a private citizen.

As a result of this act, $\mathrm{Mr}$. Sorenson resigned his seat on the city council - it isn't clear whether he was forced to do this to keep his job.

According to pundits, this sorry spectacle was a threat to democracy. Said one editorialist, "It was a mean, cheap tactic on the part of a trade union, and no credit to the labour movement as a whole."

Mean? Yes. Cheap? Yes. Petty? Again, yes. But let's put things into perspective. The union, and all other depositors for that matter, have every right in the world to withdraw funds at any time they wish, for whatever reason seems sufficient to them. That, after all, is the meaning of a demand deposit. Such an arrangement is the embodiment of a contract between two mutually consenting parties, the depositor and the lending institution. In choosing to withdraw $\$ 25,000$, even for this spiteful reason, CUPE Local 389 was thus completely within its moral and legal rights. The $\$ 25,000$ is owned by the union. It and it alone has the sole right to determine its place of investment. Neither Mr. Sorenson nor the credit union for which he works has any right to determine where, how or whether this money shall be invested. Certainly their rights have not been abridged by the decision of the proper owners ${ }^{10}$ to withdraw the money from the care of the bank.

Noc only has the union every right to withdraw its funds for this reason, but other groups in society act in the same way without the wailing and gnashing of teeth visited upon CUPE.

Does anyone really doubt that corporations deposit and withdraw their funds in accordance with what they perceive as their own best interests? Certainly, church groups and others have publicly withdrawn holdings from banks which have invested in South Africa, or which support firms which are not "ecologically sound." And do not consumers continually pick and choose amongst the stores they will patronize, partially on the basis of boycotting merchants who displease them, sometimes on the most subjective of grounds? Why should unions be singled out for opprobrium for stewardship of their own money?

Then there is the difficulty of legally prohibiting such behavior. How could government stop this practice without dictating how to spend and invest private property? Any attempt to stop such practices would surely involve us in the scenario warned against so eloquently by George Orwell, in his book Nineteen Eighty-Four.

Contrary to the political commentators, this act of boycott was a moderate response by the union, certainly when com-

\footnotetext{
${ }^{10}$ We are assuming for the moment, in effect, that CUPE is a legitimate or non coercive union organization. Unfortunately, this is not at all the case. Their illegitimacy stems, however, not from their decision wo boycott Sorenson's bank; it is a result of their failure to renounce initiatory violence as a means of conducting business.
} 
pared to the acts which are customary to organized labour. Canadian unions, and also those in the U.S., as a matter of institutional arrangement are commonly allowed to invoke the coercive power of government in order to pursue their own commercial goals. This is their defining characteristic, for organized labour is one of the few institutions in our sociery permitted to use the threat of fines and/or jail sentences to prohibit competition.

This is a reference, of course, to the manner in which nonunion workers who compete with unions for jobs are treated. They are branded as scabs and pariahs. Canadian law forces the employer to "bargain fairly" with the union, and thus prohibits him from dealing with those who would compete for the jobs of organized workers. Even though mutually agreeable contracts could be made between employers and "scabs" for the jobs and pay-scales rejected by striking workers, labour legislation forbids such an occurrence.

So there we have it. On the one hand, a union boycott which violates no rights, but which is roundly condemned by commentators. On the other hand, the union practice of restricting entry to employment which is a patent violation of the rights of every non-union would-be competitor for these jobs. And yet this immoral practice is condemned by practically no one, and even enjoys the prestige and protection of modern law.

A greater travesty of justice can scarcely be imagined.

\section{Illegitimate Unionism}

Picketing

Now let us consider several illegitimate union activities. These are acts which coercive unions engage in, but which noncoercive unions totally eschew. Picketing, for example, is morally illicit, and therefore should be outlawed, because it is equivalent to a threat or an initiation of physical force. "This

"In the typical legal analysis of this subject, only secondary picketing (which is not directly aimed at the employer, but rather at third parties, in order to in this way more effectively impact the employer) is even discussed. Implicit in this analysis is the understanding that primary picketing is a legitimate activity. See for exampie Gall activity must be clearly distinguished from a boycott. In picketing, the object is to coerce and often physically prevent people who would like to deal with the struck employer (suppliers, customers, competing laborers - "scabs," or strikebreakers) from so doing. In a boycott, in contrast, the aim is to mobilize those who already agree with the strike to refrain from making the relevant purchases. True, one may try to convince neutral parties, but in a boycott the means of doing so are strictly limited to non-invasive techniques. Once physical encroachments are resorted to, a boycott becomes converted into picketing.

There are those who characterize picketing as merely "informational." In order to see the problematic nature of such a claim, try to imagine what our response would be were McDonald's to send its agents, hundreds of them, carrying big sticks with signs attached to them (picket signs), to surround the premises of Burger King, or Wendy's, in order to give "information" to their customers or suppliers. In like manner, we do not allow Hertz to picket Avis, or General Motors to picket Ford. There is absolutely no doubt that such activities would be interpreted, and properly so, as an attempt to intimidate. If these firms wish to convey information, they have other avenues open to them: advertising, direct mail, contests, give-aways, bargains, etc. And the same applies to a union. If it wishes to communicate, it must restrict itself to these activities.

Nevertheless, it is continually asserted that the pickets are only at a job site in order to impart the information that a strike is in progress; however, it is "conceded" that the picketers become enraged if they see anyone engaging in commercial endeavors with the struck employer. The attempt, here, is to claim that these "interferences" (people going about their ordinary business, attempting to ignore the strike) are responsible for the violence which is endemic on a picket line. But one cannot have it both ways. Either there is only knowledge being given out, or there is not. If there is, then how do we account

(1984). 
for the typicality with which violence arises on the picket line? Are its members particularly "sensitive?"

But this is all beside the point. Even if violence was never associated with picket lines, this would only prove they were so successful in their intimidation that none was necessary. The libertarian non-aggression axiom precludes both the actual initiation of violence as well as the threat thereof; thus, even picketing which is (so far) non-violent is a threat to all would-be crossers of the picket line.

A more accurate interpretation of picketing (whether primary or secondary) is as a nuisance or harassment. This is precisely how it would be regarded were it to take place in any other commercial or personal arena.

Suppose, that is, that a person vacates the premises of landlord $A$, and patronizes landlord B instead. Surely the courts would cast a baleful eye on $A$, if he, together with his family, cronies, and business associates, began to picket the tenant for being "unfair." Or take another case. Suppose that a man divorces his spouse, and then along with all his friends "pickets" the home of his ex-wife, warning off possible suitors. Would this be considered an informational exercise in free-speech rights? Hardly. On the contrary, it would be clearly seen for the harassment it is, and be summarily prohibited by any court in the land.

Can we afford any less rigorous a definition of justice in labour-management relations?

There is one complication, however. It concerns the legal status of the area on which the picketing occurs. If the picket line operates on private property, the analysis from the libertarian perspective is clear and straightforward: this activity may properly occur only with the permission of the owner. Otherwise, as we have seen, it must be interpreted as oppressive. Unfortunately, in a series of cases concerning the right of picketing and leafletting, the courts have undermined the private property status of streets and thoroughfares in shopping malls, by a finding that these areas are "public places." But they were privately built, are privately operated and maintained, and therefore ought to be considered as part of the private sector - their use to be determined by their owners.

It is far more difficult to determine the proper use of public streets and sidewalks. For the libertarian theorist, these areas are a conundrum. Given that it is morally improper and economically inefficient for the government to have nationalized them in the first place (Block, 1979), it is difficult to determine whether or not picketing should be allowed on the public sidewalk, for example, right in front of the employer's premises. The determination of whether to allow any public assembly (e.g., a parade) to disrupt the normal traffic patterns on government streets is essentially an arbitrary one. It depends upon public pull, not on philosophically determined rights.

Perhaps the best course of action in this moral vacuum is to treat the picketers as if they were merely offering information, as they so vociferously claim. In this case, the best analogy is the man who walks up and down the street with sandwich board placards advertising for a local merchant. Would the court ailow one or even two such moving billboards? Certainly, provided that they kept some distance between themselves, and did not interfere with passersby. Would the court allow dozens of tightly packed sandwich board carriers who impeded the normal traffic flow? Certainly not. We conclude from these considerations that striking unionists who use "public property" should be treated exactly like any other group of people attempting to advertise information. If the courts would allow one or two sandwich boarders the use of the public sidewalk, they should extend the same right to informational union picketers. And where they would deny this right to dozens or hundreds of sandwich boarders, they must act in the same way with regard to organized labor.

\section{Scabs}

Who are the innocent persons against whom coercive union violence is commonly directed? These are the people at the bottom of the employment ladder, the least, last, and lost of us, the individuals after whose welfare we should take particular concern if we have any regard for the poor. They are, in a word, "Scabs." 
Now scabs have had a very bad press. Even the appellation ascribed to them is one of derogation. But when all the loose and inaccurate verbiage is stripped away, the scab is no more than a poor person, oft-times unskilled, uneducated, under-or unemployed, perhaps a member of a minority group, who seeks nothing more than to compete in the labor market, and there to offer his services to the highest bidder.

In fact, it is no exaggeration to consider the scab the economic equivalent of the leper. And we all know the treatment with regard to lepers urged upon us by moral and ecclesiastical authorities.

In their pro (coercive) union stance, defenders of organized labor expose themselves as untrue to the morally axiomatic principle of the preferential option of the poor, which was adumbrated by both the U.S. and Canadian Conferences of Catholic Bishops. ${ }^{12}$ The "poor," in this case, are not the princes of labor, organized into gigantic, powerful and coercive unions. Rather, they are the despised, downtrodden and denigrated scabs. ${ }^{13}$

\section{Violence}

A strange adventure recently befell Patrick McDermott, the 27 year old son of Canadian Labor Congress president Dennis McDermott. Young Patrick was innocently riding a bus in suburban North York, in Ontario, when he witnessed a beating in the street. Dianne McIntyre, aged 42, was being assaulted by a man - whereupon our hero jumped off the bus, came to the rescue of the damsel in distress, and for his pains was wrestled to the ground by four other men, colleagues of the hoodlum battering Mrs. McIntyre, and was kicked and punched while he was down.

"No big deal" you say? "Happens every day?" Well, yes,

\footnotetext{
12 For a critique of these documents, see Block (1986, 1983).

1'Nothing said here mitigates against the legitimacy of voluniary unions, those which restrict themselves to mass walkouts and other non-invasive activity. The onily difficulty is that at present, such encities are non existent, at least in North America, to the best of the present author's knowledge.
}

unfortunately; street violence seems to be part and parcel of modern day life, not only in the U.S., but increasingly in Canada as well.

But this case was exceptional. The victimized woman was crossing a picket line at the main Visa credit card center for the Imperial Bank of Commerce, and the five bully boys were bank workers, engaged in a labor strike against this financial institution. What a position to be in for Patrick McDermott, a staunch union supporter in his own right, and son of the outgoing president of the C.L.C.!

Mr. McDermott the younger tried to remain loyal to his principles. That is, to both of them: chivalry and defense of innocent persons against assault and battery on the one hand, and unionism on the other. Although suffering from an arm injury, bruised ribs and a split lip in his confrontation with the minions of organized labour, he stated that he still believes "in the strike and the cause, but when it comes to goons hitting defenseless women, it's got to stop. That guy should be thrown out of the union."

This, however, is too facile, by half. Unionism as practiced in the Western democracies is intrinsically a violent, confrontational and physically aggressive institution. Young Mr. McDermott cannot have it both ways. He must either renounce the "cause," or give up on his principle that goons should not be able to beat up innocent persons.

Why is this? How can it be that a widely respected institution, organized labour, necessarily initiates violence against non-aggressing people?

The reason is straightforward. Actual union practice, and the labour codes of the land which underlay it, are predicated on the assumption that competition, no matter how well it works elsewhere in the economy, is simply inappropriate for the labour market. And not only inappropriate, but deserving of legal penalties as well. Labour enactments commonly mandate that the employer "bargain fairly" with a union, when what he may want to do most of all is ignore his striking employees entirely, and hire competing workers (i.e., "scabs") in their place. Some Canadian provinces (e.g., Quebec) prevent manage- 
ment from hiring temporary replacements for the duration of the labour dispute; others allow this, but insist that the firm not deal more favorably with these laborers than with its unionized work force. If the employer declines to be bound by these restrictions, he is liable to fines or even jail sentences - which is certainly equivalent to visiting violence against a person, the employer, for doing no more than encouraging competition in the labour market.

It is perhaps for this reason that the police and courts turn a blind eye - or even a sympathetic one - to situations where union violence is directed against the employer, or, in the case of Mrs. McIntyre, against those who support scab workers by crossing picket lines. "If the government will physically prohibit labour market competition anyway, why penalize organized labour for doing the same thing?" seems to be the prevailing opinion.

A moment's reflection will convince us that this practice union violence or government violence practiced against employers and/or scabs - is completely unjustified. The non-employed competing workers (scabs) have every bit as much right as the striking unionists to compete for jobs offered by the employer. Any other conclusion would set up two classes of people - unionists and scabs - with different types of rights. But all people have the same human rights to compete for employment, without being victimized by physical violence, whether from unionists or policemen.

As for the assault and battery perpetrated on Patrick McDermott and Dianne Mclntyre, a union spokesman termed the incident "minor," and said there were no plans for disciplinary action against the pickets who injured them! And of course the police did nothing to quell this violence in our streets, even though they and all citizens would have been outraged had this situation occurred in any context other than that of a labour strike.

\section{Breakdown of Law and Order}

One way to understand this phenomenon of the widespread acceptability of union violence is to focus on the role of the police. They are, after all, supposedly society's fail-safe mechanism against violence. The problem, however, is that this institution, too, has been beset by the virus of accepting unions as legitimate. ${ }^{14}$

According to Mr. Bob Stewart, Chief of Police of Vancouver, one of Canada's largest cities, the use of violence by his constables is inappropriate in a labour dispute. Happily, this man is not a complete pacifist; this view only applies, it would appear, with regard to union unrest. Addressing a meeting of the Atlantic Police Chiefs, he stated "the role of the police officer is to maintain peace and order and not be seen as partisan." ${ }^{\text {t5 }}$ The reason for this low profile, it was contended, is that a labour dispute is really a contract dispute between two parties, and not a dispute with police.

It is easy to understand the motivation behind this stance. Canada sees itself as a very stable, polite and civil society, and union-management confrontations are potential tinder boxes. The last thing desired is to fan the flames of violence that have so unfortunately erupted in other corners of the globe.

Nevertheless, there are grave flaws in such a view. Were it to have come from someone else, who did not occupy such an exalted place in the country's law enforcement hierarchy, it could be easily dismissed. But when it is stated by a high ranking police official, it has great capaciry to do harm.

First of all, there is the danger that strikes will become more violent, noc less. If the police announce beforehand that they will not energetically quell labor violence, this may encourage hotheads to give vent to their more base instincts.

Secondly, it is the very rare case indeed when a person picks a fight directly with a policeman (except, perhaps, when the officer of the law is disguised.) Typically, the services of the police officer are called upon when there is a dispute between two parties, neither of whom is engaged in a direct altercation with the police. But when two men are fighting in a public

${ }^{14}$ For a moral and religious defense of unionism, see Novak (1984), U.S. Bishops (1984); for a critique, see Block (1986).

${ }^{15}$ Vancouver Sun, July 8, 1987. 
street, or when one is assaulting and battering another, we expect the policeman to intervene, with force if necessary, even if the dispute does not directly concern him. After all, we the citizens supposedly pay taxes for police protection, and we expect these services when we are attacked, not only when they are.

Thirdly, this philosophical position is woefully ignorant of what actually takes place during a strike. Superficially, it is a confrontation between employer and union, who are, or in some cases once were, parties to a labour contract. But it is only in the rare instance that the unionized workers attack their employer's plant, or their employer; after all, they work there, and when the dispute is solved, they typically prefer to have a plant in which to return back to work.

On the contrary, a strike is almost always a dispute between parties who are unrelated by contract. That is, between organized labour and replacement workers, or strike breakers. The union brands these individuals as "scabs," and then initiates violence against people who are guilty only of daring to bid for the jobs currently claimed by the unionists.

Further, it is not really important whether or not the two disputants are contractually linked. Even if they are, it is still the sworn duty of the police to stop - by force if necessary either side from initiating violence against the other.

That a Canadian Police Chief purposefully wishes to take a "low profile" under such circumstances only indicates he does not really understand the purpose or significance of his job.

\section{Job Ownership}

Another defense of picketing and attendant violence concedes that this is a physically aggressive activity, but asserts that it is not an initiation of coercion, but rather a defense of private property rights, namely the jobs of the striking unionists. There is a certain superficial plausibility in this rejoinder. However, the "scab" is not stealing the job of the striking coercive unionist. A job, by its very nature, cannot be owned by any one person. Rather, it is the embodiment of an agreement between two consenting parties. In the case of the strike, organized labor is unsatisfied with the offer of the employer. It is publicly renouncing this offer. It therefore cannot be said that these workers still "have" these jobs. ${ }^{16}$ Under laissez faire, all people are allowed to compete for jobs in a free labor market. It is a vestige of the guild system to think that there are two groups of people with regard to employment at any given plant: the coercive unionists, who own the jobs, or have a right to them, and all other people, who must refrain from bidding for them.

To some extent we are fooled by the very language we use in order to describe this situation. We speak of " $m y$ " job, or "your" job, or "his" job, or "her" job; this use of the possessive pronoun does seem to indicate real possession, or ownership. We also speak of "my" tailor, or "my" employee, or "my" customer, and yet it would be nothing short of grotesque to assign ownership rights to any of these relationships. All of them are based on muruality, not ownership on the part of either person. This use of the term "my" does not imply ownership. If it did I could forbid "my" employee from quitting his job. If it were "my" customer, I could prevent him from taking his business elsewhere, to a compecitor. And if it were "my" tailor, it would be a violation of my rights if he moved to another city, retired, or entered a new occupation.

A job is an embodiment of an agreement between two consenting parties - employee and employer. It cannot be the possession of only one of them. A worker no more owns "his" job than does a husband own "his" wife. A striking union which forcibly prevents the employer from hiring a replacement is like a husband who divorces his wife - and then threatens to beat her up, and any prospective new suitor as well - if she tries to remarry. Just as one spouse may now divorce the other for any reason or for none at all, the employer should be able to fire an employee without being compelled to show "cause." Our laws do

${ }^{16}$ We must assume that there is no longer a valid employment contract in force between the employer and employees. If there is, then the workers do indeed "own" these jobs, but only because of the contract (assuming that it was initially agreed upon without duress), not because of any superior satus they may claim as members of the union caste. 
not force the worker to justify a decision to quit his job, and the employee-employer relationship should be an entirely symmetric one.

\section{Sweat Shops}

What of the claim that without picketing, coercive unions would be rendered virtually powerless, and in the absence of strong coercive labor organizations, the working people would be forced back into the "sweat shops." First of all, even if this claim were true, picketing would still be unjustified, and a violation of the basic libertarian premise against the initiation of violence. Secondly, even if coercive unions were all that stood between the sweat shop and present living conditions for their members, it still does not follow that the lot of working people would be improved by picketing. For this activity is aimed not so much at the employer as at the competing worker, the strike breaker. The major aim of the picket line, as we have seen, is to prevent alternative workers from attaining access to the job site. Indeed, the very terminology employed by coercive unionists to describe him, "scab," is indicative of the extreme denigration in which he is held. But these people are working people too. Further, as we have noted, they are almost always poore ${ }^{17}$ than the striking coercive unionists. This is seen by the fact that the "scabs" are usually more than happy to take the offer spurned by the strikers. So if there is anyone who needs to be protected from the specter of the "sweat shop," it is not the coercive unionist, but the scab.

Thirdly, it is profoundly mistaken to believe that the modern level of wages depends upon coercive union activity. As any introductory economic textbook makes clear ${ }^{18}$, wages depend,

17The Canadian and U.S. bishops are on record as supporting the "preferential option for the poor." Yet, inconsistently, they support coercive unionism as against the "scabs," who are their major victims. However, the scab may be considered as the economic equivalent of the leper. But the ecclesiastical and biblical authorities urge upon us the kindest of treatment with regard to lepers. Therefore, their own analysis of the scab is illogical.

"Even those written by authors who are far from sympathetic to the free enterprise system. See for example Samuelson (1970, chapter 29.) to the contrary, on the productivity of labor. If wages are bid above productivity levels, bankruptcy and consequent unemployment will tend to result. ${ }^{19}$ If wages somehow find themselves below the rate of marginal revenue productivity, other employers can earn profits from bidding these workers away from their present employers - by continually improving the job offer until wages and productivity levels come to be equated.

There is abundant evidence to support the view that coercive unionism cannot be credited with the explosion of wages and living standards. For one thing, the modern coercive labor movement has only been with us in this century, and only gained much of its power (in the U.S.) with the advent of special legislation in the 1930s, when its share of the labor force rose from $5 \%$ to $20 \%$ (Rothbard, 1978, p. 84). And yet wages, welfare and standards of living have been on the increase for hundreds of years before that. For another, the economies of countries of southeast Asia such as South Korea, Taiwan, Hong Kong, Singapore, have been burgeoning in the last several decades, in the virtual absence of unionism, coercive or voluntary (Novak, 1987). As well, there have been sharp wage increases in industries - within countries with a strong labor movement - which are completely unorganized. Examples include banking, computers, even house cleaners.

The comparison between the U.S. and Canada is aiso instructive. In 1960, the (coercively) unionized sector in both countries was about $30 \%$; by 1988, labor organizations represented over $40 \%$ of the Canadian work force, but less than $15 \%$ in the U.S. If the union-as-the-source-of-all-prosperity hypothesis were correct, we would have noted a slippage toward sweat shop labor conditions in the U.S., and an era of extreme affluence in Canada. Needless to say, that has not at all been the

19This was the fate of West Virginia, which fell victim to the activities of John $L$. Lewis, and organized labor in the coal fields. 
case. $^{20}$

\section{Homework}

A man's home may be his castle, but not as far as working there is concerned - at least according to legislation which restricts commercial activity in one's own domicile.

Originally, such laws were placed on the books in order to support legislation concerning child labor and compulsory minimum wages. As well, the unions protested vociferously that homeworkers would be very difficult to organize, and the result would be a return to sweatshop conditions.

In the modern era, however, the people who wish to work at home are more likely to be reasonably well off women who wish to earn a bit of extra pin money. For example, there was a "kerfluffle" over several hundred women in the New England states who were knitting snow mittens and ski caps, and who justified this practice on the grounds of "freedom of enterprise." And, as if to show that politics does make strange bedfellows, they also defended themselves on the basis of womens' liberation. Being able to work at home was the only way that many of them could work at all - while continuing to watch over their children.

The debate over home knitters is really only a tempest in a teapot. At most, it involves several thousand seamstresses in an industry that has been on the verge of being supplanted by technolozy for many years now. Of far greater statistical significance will be the likely move of clerical workers from office to home. This is now just beginning to be made possible

${ }^{20} \mathrm{Grubel}$ and Bonnici (1986, pp. 40-43). As well as the differing unionization rates, the two countries also experienced widely divergent unemployment insurance policies. In 1970, the U.S. and Canada both spent about $0.9 \%$ of their G.N.P. on unemployment insurance benefits: by 1983, the U.S. had maintained its previous level of $0.9 \%$, but Canada's had risen to $3.4 \%$, an increase of $277 \%$ ! (pp. 44-47). These two events had a profound effect upon the unemployment rates of the two North American neighbors. Tradicionally, U.S. and Canadian unemployment rates have moved together within a narrow range. In 1963 for example, they were both slightly less than $6 \%$. But as the disparate unionization and unemployment policies began to take effect, the Canadian rate began to exceed that for the U.S. In the early 1980s a gap of some $4 \%$ opened up (p. 2). by technological breakthroughs in computers and word processors, and has thus so far amounted to only a trickle. If present trends continue, however, it is possible that this small stream could turn into a tidal wave.

If this occurs, the union argument that cottage industry is synonymous with sweat shop conditions will be given even wider publicity. It is incorrect, and public policy based on its truth will, as a result, be counterproductive. We can no longer countenance the idea that unionization is all that stands between the laborer and the sweat shop. Thus, there is simply no case for interfering with the institution of home work, no matter how big it becomes.

And there is every moral reason for allowing this new form of industrial organization. People have a natural right to do whatever they please, provided only that their actions do not infringe on the rights of others to do exactly the same. Those who favor both unionism and women's liberation will have to make a choice: one or the other. As this example shows, they cannot have it both ways.

\section{Unequal Bargaining Power}

A major reason given by some commentators for their unseemly support of unionism is that employers frequently possess greater bargaining power than do employees in the negotiation of wage agreements. Such unequal power may press workers into a choice between an inadequate wage and no wage at all, it is aileged.

But this rather seriously misconstrues the process of wage determination. In a free labor market, wages are basically set by the marginal revenue productivity of the employee - not on the basis of bargaining power, scale of enterprises, or size of labor units. Were the bargaining power explanation for wage rates correct, remuneration would be negatively correlated with the concentration ratio; that is, industries with fewer employers would pay lower wages than ones with many - and pay would be unrelated to measures of productivity such as educational attainment. Needless to say, no evidence for this contencion exists. 
The typical reason for supposing that there is unequal bargaining power ${ }^{21}$ is that there are more employees than employers. ${ }^{22}$ If so, this is hardly sufficient to establish the case. Let us assume that bargaining power is defined in such a way that when there is a difference of opinion over wages, or a dispute about them, the person with the greater bargaining power is more likely to attain his goal than is the person with the lesser bargaining power. ${ }^{23}$. But in actual point of fact, the likelihood of attaining one's goal in a bargaining situation depends almost entirely on whether the wage is above, below, or equal to equilibrium, e.g., productivity levels (Hutt 1973, ch. 5). In the first case, the employer will have more "bargaining power," as wages will tend to fall in any case; in the second case, the employee will have more "bargaining power," as the market will dictate an increase in wages. One may say, if one wishes, that in the third case "bargaining power" is equal, since wages will tend not to change. But on the basis of Ocham's Razor it would be more scientific to dispense with the concept of bargaining power ${ }^{24}$ entirely, and confine our purview to basic

${ }^{21}$ For a particularly unsophisticated version of this view, see Weiler (1980, p. 26), who states: "... workers realized that they had no real leverage in dealing with their employer on an individual basis. True, any one employee might threaten to quit if her pay was not raised. But any sizable employer, let alone a national bank. could aiways get along without that single employee, who ability and contribution is fungible and who is easily replaced if and when she makes her exit. By contrast the employee will find that she cannot make do without her employer, since she needs a job to earn a living, and jobs may not be too plentiful."

:Other attempted justifications of this thesis are that employers are typically more wealthy than employees, and that it is easier for the former to replace the latter than the inverse.

To define bargaining power in the opposite manner (so that the person or group with greater bargaining power would tend to lose disputes over wages) would be to render the argument ludicrous.

2'There are more customers than merchants (and more whites than blacks, more right handed persons than southpaws, more brunettes than blondes). Does this mean that the latter have more "bargaining power" than the former whenever the two are embroiled in competition, or in a dispute over the terms of trade? Not a bit of it. Customers have more "bargaining power" than merchants when prices are presently above equilibrium. that is, when goods are in surplus, because prices tend to be fall in such cases. Likewise, merchants have more "bargaining power" than consumers when prices are below equilibrium, i.e., when there is a shortage of the good in question, supply and demand analysis of the labor market.

The bargaining power notion is also erroneous in that it disregards the basic economic tenet that in a free market wages tend to be equated with productivity levels. If wages are higher than worker productivity, the enterprise tends to become bankrupt; if lower, the firm suffers a high quit rate, as employees are enticed away by other employers. It is only when wages and productivity are equal that there is no automatic market impetus for change (Hazlitt, 1979).

Weiler sneeringly rejects this as "sophisticated economic analysis," and thus a "somewhat romantic notion," that is somehow out of step with what "has always seemed intuitively clear to workers - and to their employers." Continues Weiler (1980, pp. 26,7):

In real life, labour markets are notoriously imperfect. There is no central clearinghouse to set an auction price for labour. Workers are poorly informed about alternative jobs and comparative compensation. Once the average employee has invested a significant part of his working career in a single job, he faces tangible and psychological barriers to moving on. Thus employers have the effective ability to quote the price they will pay for labour and to make that price stick.

On closer inspection this latter statement sounds more like the ravings of a Marxist than the sober commentary of a scholar of labor markets. Weiler goes on to assert that "typically, employers (do not) set those wage rates at exploitative levels," but this only compounds the fallacy. Why, if they have the power to do so, do supposedly profit-maximizing firms refrain from "exploiting" labor?

Nor do the other parts of this analysis withstand scrutiny. No central clearinghouse for labor is necessary for the smooth functioning of labor markets, nor is worker information

because prices tend to rise in such cases. 
required. As long as there is competition between employers, and knowledge of wages on at least one side of the market - for example that of the employer - the market operates inexorably to equate compensation and productivity levels. And further, to the extent that long-term employees face psychological costs in job switching, they are earning psychic profits by remaining with their present employer. If they are reluctant to leave, this is because they are earning non-monetary income over and above their actual salaries by remaining precisely where they are. ${ }^{25}$

\section{Labor Legislation}

It follows from our analysis of coercive unionism that much of our present labor legislation is mischievous and misguided. If voluntary association and mutual consent are the only legitimate foundations of employment; if it should be strictly forbidden for one group of workers to forcibly prevent another ("scabs") from competing for jobs; then it follows that government-made laws which are inconsistent with these principles are incompatible as well with the libertarian legal code. For example, there should be no laws which compel the employer to "bargain in good faith" with any one set of employees; he should be allowed to deal with anyone he wishes. Further, all legislation prohibiting an employer from firing striking workers, and hiring replacements on a permanent basis, should be repealed. Says Rothbard (1973, pp. 84-85):

It is true that the strike is a peculiar form of work stoppage. The strikers do not merely quit their jobs; they also

Weiler (1980, p. 27) maintains, without benefit of citation, that "empirical investigation of labour markets in the absence of collective bargaining discloses a remarkable dispersion of wage rates paid to workers with comparable skills in comparable jobs and in comparable industries and regions - all contrary to the hypothesis of competitive markets, which are supposedly marred by trade unionism." But how large is "remarkable"? Who is to determine that the skills, industries and regions are truly comparable? I vory tower researchers? Nor can these unnamed studies take into account non monetary psychic on-the-job earnings, attained, as Weiler himself postulates, by long tenure on the job. assert that somehow, in some metaphysical sense, they still 'own' their jobs and are entitled to them, and intend to return to them when the issues are resolved. But the remedy for this self-contradictory policy, as well as for the disruptive power of labor unions, is not to pass laws outlawing strikes; the remedy is to remove the substantial body of law, federal, state, and local, that confers special governmental privileges on labor unions. All that is needed, both for libertarian principle and for a healthy economy, is to remove and abolish these special privileges.

These privileges have been enshrined in federal law especially in the Wagner-Taft-Hartley Act, passed originally in 1935, and the Norris-LaGuardia Act of 1931. The latter prohibits the courts from issuing injunctions in cases of imminent union violence; the former compels employers to bargain 'in good faith' with any union that wins the votes of the majority of a work unit arbitrarily defined by the federal government - and also prohibits employers from discriminating against union organizers .... Furthermore, local and state laws often protect unions from being sued, and they place restrictions on the employers' hiring of strikebreaking labor; and police are often instructed not to interfere in the use of violence against strikebreakers by union pickets. Take away these special privileges ...

It is characteristic of our statist trend that, when general indignation against unions led to the Taft-Hartley Act of 1947 , the government did not repeal any of these special privileges. Instead, it added special restrictions upon unions to limit the power which the government itself had created ... The government's seemingly contradictory policy on unions serves, first, to aggrandize the power of government over labor relations, and second, to foster a suitably integrated and Establishment-minded unionism as junior partner in government's role over the economy.

\section{Conclusion}

It is an important aspect of public policy-making to examine extant labour codes with a view to revising them. In the past, 
such attempts have been superficial; they have placed bubble gum, band aid, and scotch tape solutions on a corpus in need of major surgery. Our legislative representatives must go to the heart of the matter this time out, for economic justice, the rule of law and the health of the economy depend upon it.

In the field of labour relations, the most important issue is the strike. Actually, this is misnomer, as it refers not to one act, but to two. A strike is, first, a withdrawal of labour in unison from an employer, on the part of the relevant organized employees. To this, there can be no objection. If a single individual has a right to withdraw labour services, or to quit a job, he does not lose it merely because others choose to exercise their rights, simultaneously.

There is a second aspect of the strike, however. This element is pernicious, insidious and entirely improper: the union practice of making it impossible for the struck employer to deal with alternative sources of labour, who are anxious to compete for the jobs the strikers have just vacated.

A properly revised labour code, then, would allow strikes in the sense of mass refusals to work, or quits in unison. It would entrench this behavior, as a basic element of the rights of free men. But is would limit union activity to this one option. It would thus prohibit, to the full extent of the law, any and all interferences with the rights of alternative employees ("scabs") to compete for jobs held by union members. It would end, forevermore, all picketing, and other such forms of threatened or actual violence.

Although many people think that pickets are aimed at the struck employer, they are actually an attack on competing workers ("scabs"). And just as our laws should not allow business firms to picket the premises of suppliers, competitors or customers, no group of workers should be able, by picketing, to forcibly prohibit another group of workers - almost always poorer - from bidding for jobs. A proper labour code would thus define a "legitimate union" as one which strictly limited its actions to organizing mass resignations. A "legitimate union" would eschew picketing, violence, and all other special advantages - legislative or otherwise - vis-a-vis its non-unionized competitors. This would end, once and for all, the legal fiction that workers who have left their job can yet retain any right to employment status in those positions.

We must conclude that the key distinction in any analysis of unions is between those that engage in coercion - whether directly or through the intermediation of unjust laws. And that sound public policy, in the first best sense, consists not of allowing illegitimate union activities, coupled with restricting them by the imposition of secret ballots, etc., but rather of stripping them of all coercive powers. The only just unions are those which limit their activities to boycotts, mass walkouts and other such activities that any one person has a right to engage in. When labor organizations transcend these limitations, they must be reined in, if economic justice is to prevail.

\section{REFERENCES}

Armentano, Dominick $T$.,

1972 The Mivths of Ancitrust, Vew Rochelle, N.Y.: Arlington House. Armentano, Dominick T., Antitrust and Monopoly: Anatomy of a Policy Failure, New York, Wiley, 1982.

Block, Walter

1979 "Free Market Transportation: Denationalizing the Roads," Journal of Libertarian Studies, Vol. III, No. 2, Summer 1979, pp. 209-238.

1976 Defending the Undefendable, New York: Fleet Press.

1983 On Economics and the Canadian Bishops, Vancouver, the Fraser Institute.

1986 The U.S. Bishops and Their Critics: An Economic and Ethical Perspective, Vancouver, the Fraser Institute, 1986.

$199^{\circ}$ "Private Property, Ethics and Wealth Creation," Toward an Ethic of Wealth Creation, Peter L. Berger, ed., San Fransisco: Institute for Contemporary Studies, 1990.

Friedman, Milton

1977 On Galbraith and on Curing the British Disease, Vancouver: The Fraser Institute.

1985 "Capitalism and the Jews," The Morality of the Market: Religious and Economic Perspectives, Walter Block, ed., Vancouver: The Fraser Institute.

Gall, Peter A.

1984 "Regulation of Picketing under the B.C. Labour Code: Some Cracks in the Institurional Foundacion," The Labour Code of British Columbia in the 1980s, Joseph M. Weiler and Peter A. Gall, eds., 
Vancouver: Carswell Legal Publications.

Grubel, Herbert G. and Josef Bonnici

1986 Why is Canada's Unemployment Rate So High?, Vancouver, the Fraser Inscitute.

Hayek, Friedrich $A$.

1960 The Constitution of Liberty, Henry Regnery Company, Chicago.

1973 Law, Legislation and Liberty, The University of Chicago Press, Chicago.

1989 The Fatal Conceit: The Errors of Socialism, Chicago, The University of Chicago Press.

Hutt, W. H.

1973 The Strike Threat System: The Economic Consequences of Collective Bargaining, New Rochelle, N.Y., Arlington House.

1989 Trade Unions: The Private Use of Coercive Power," The Reriew of Austrian Economics, Vol. III, 1989, pp. 109-120.

Leoni, Bruno

1961 Freedom and the Law, New York: Van Nostrand.

Mises, Ludwig von,

1966 Human action, Chicago: Regnery.

Novak, Michael

1987 Will it Liberate? Questions about Liberation Theology, New York, Paulist Press, 1987

Novak, Michael et. al.,

1984 Toward the Future: Catholic Social Thought and the U.S. Economy - A Lay Letter, New York: Lay Commission on Catholic Social Teaching and the U.S. Economy, 1984.

Ohashi, T.M. and T.P. Roth, eds.

1980 Privatization: Theory and Practice, Vancouver: The Fraser Institute. Petro, Sylvester

1957 The Labor Policy of the Free Society, New York, Ronald Press.

Reynolds, Morgan $O$.

1984 Power and Privilege: Labor Unions in America, New York: Manhattan Institute for Policy Research.

Rothbard, Murray N.

1970 Man, Economy and State, Los Angeles, Nash.

1973 For New Liberty, New York, Collier.

1983 The Ethics of Liberty, Atlantic Highlands, N.J. Humanities Press.

Samuelson, Pau

1970 Economics, New York, McGraw-Hill, 8th edition, chapter 29.

Schmidt, Emerson P.

1973 Union Power and the Public Interest, Los Angeles, Nash.

Simons, Henry C.

1948 Economic Policy for a Free Society, Chicago, University of Chicago

Press.
Sowell, Thomas

1983 The Economics and Politics of Race, New York, Morrow.

U.S. Bishops' Pastoral Letter on Catholic Social Teaching and the U.S.

Economy, Origins: NC Documentary Service, November 15, 1984, Vol. 14, No. 22/23.

Vonnegut, Kurt

1982 "Harrison Bergeron," Discrimination, Affirmative Action, and Equal Opportunity, Walter Block and Michaei Walker, eds., Vancouver: The Fraser Institute.

Walker, Michael ed.,

1976 The Illusion of Wage and Price Control, Vancouver: The Fraser Institute.

1988 Privatization: Tactics and Techniques, Vancouver: The Fraser Institure.

Weiler, Paul

1980 Reconcilable Differences, Toronto: Carswell.

Williams, Waiter E.

1982 The State Against Blacks, New York: McGraw-Hill 